\title{
Louis Alexander: We looked, listened and learned
}

TOM McARTHUR reflects on the life and indefatigable work of the Englishlanguage materials writer L.G. Alexander, who died on June 17th this year at the age of 70, after a long and patient struggle with leukemia

MY AWARENESS and appreciation of the impact of Louis Alexander on English-language teaching worldwide has tended over the years to come in waves. The most recent such wave was when I read a report on developments in China in the 1990s by He Qixin of Beijing Foreign Studies University, in which he notes:

All things considered, it is no exaggeration to say that China has the largest English learning population in the world. No organization is able to provide reliable statistics indicating the exact number of English learners in China, simply because numerous English language training centers all over the country... are offering a great variety of English courses for people from all walks of life... This is also true with publishers specializing in foreign language education. One can find a striking example of the popularity of English education in China in the two sets of English textbooks I have published in the last ten years. The first is a listening comprehension course book prepared for English majors, entitled Listen to This. It was published first in 1992 and has sold 1.5 million copies. The second book is New Concept English, a collaborative work with L. G. Alexander, a well-known British scholar. This new edition, specifically prepared for Chinese learners, first came out at the end of 1997 and has sold nearly 1.5 million copies during the first four years of publication.

(<www.miis.edu/docs/langpolicy/ch15.pdf>, consulted Aug 02).

He Qixin might well have also noted that Louis Alexander's books were widely available in China some twenty years before the date mentioned above, and have been so successful that he has long had celebrity status there. His work has also long been well known and received in many other places where English is learned as the global lingua franca. Yet, regrettably, he was not a prophet in his own land. English is the world's key language, but British movers

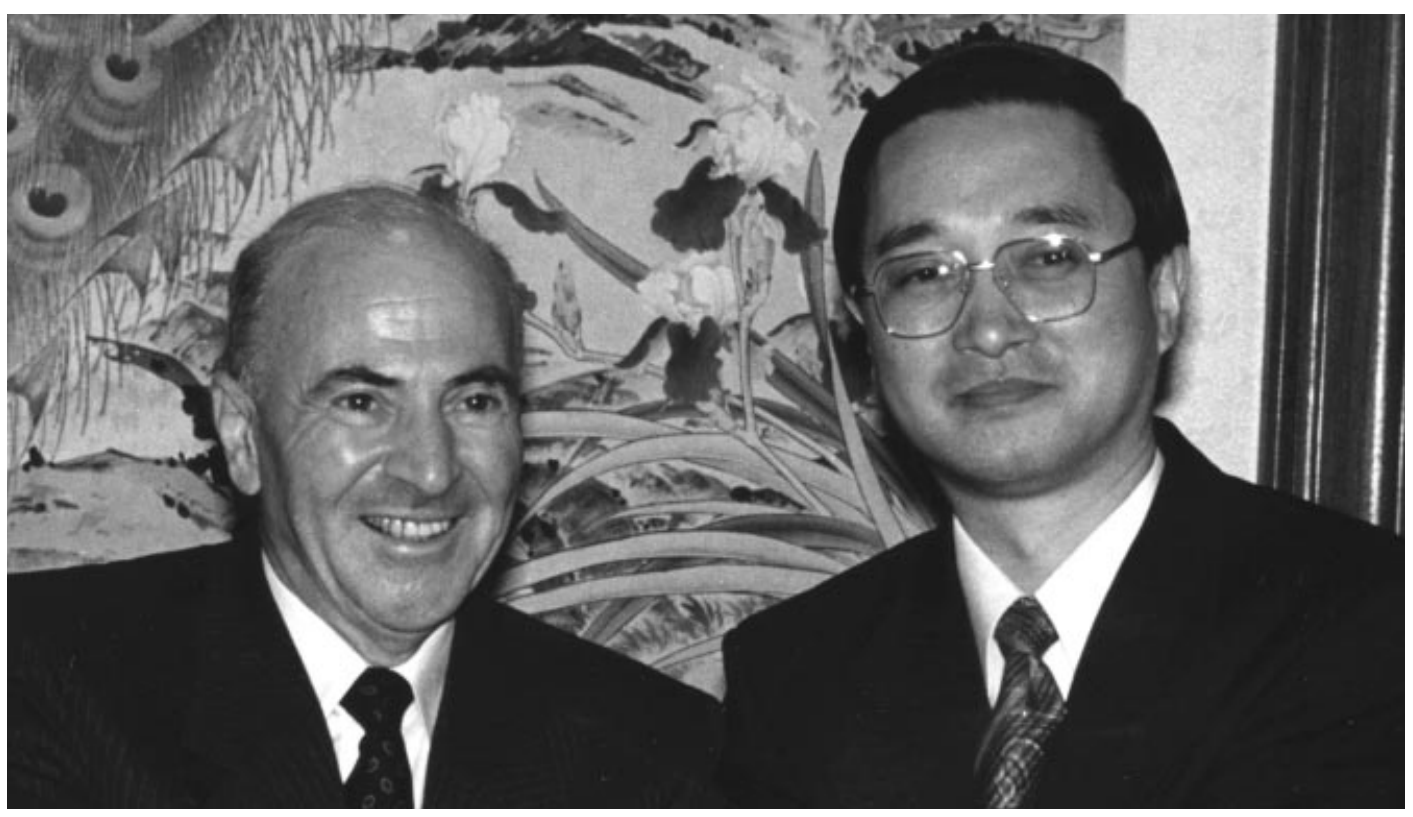

Louis Alexander and He Qixin 
and shakers in ELT have generally been little noticed At Home.

Louis George Alexander, whose father was Greek and mother Australian, was born in London in 1932. He spent the years of the Second World War in Australia with his mother, and when he returned he studied first at Godalming Grammar School then at the University of London. He was introduced to teaching during his National Service in the British Army (1954-56), as an Educational Corps instructor in Germany. He then embarked on a career in English-language teaching and materials writing which has immensely enriched both ELT and language teaching at large. Highlights of his global career include:

- Teaching in Greece (1956-65) in the Department of English at the Protypon Lykeion in Athens (now the Skholi Moraiti/Moraitis School), for most of that time as head of department.

- Serving as an adviser to the Deutscher Volkshochschulverband (German People's High School Association), 1968-78, and contributing to the design of two major English examinations in German Adult Education.

- Serving as a member of the Council of Europe's committee on modern language teaching (1973-78) and as one of the authors of the syllabuses The Threshold Level (1975) and Waystage (1997), which have provided a basis for many courses within the framework of the 'communicative approach'.

- Co-authoring English Grammatical Structure (1975), a basic syllabus of graded structures for language-learning purposes, which he regarded as able to blend well with the communicative approach (a viewpoint which I have long shared).

- Serving in 1986-88 as adviser to the University of Cambridge Local Examinations Syndicate (UCLES) for the Cambridge Certificate in English for International Communication.

- Working in 1988 with UNESCO on the project Junior English For China.

Louis worked in the main with Longman, a venerable British (and American) publisher now part of the Pearson Group. He contributed greatly to Longman's success and image in ELT, his innovative courses long occupying centre stage in its list. His Longman course-books include: A First Book in Comprehension (1964), First Things First and New Concept English
(1967), Look, Listen and Learn! (1968-71), Target (1972-74), Mainline (1973-81), Follow Me (1979-80, with the BBC), and Plain English (1987-88). He also produced a range of student practice books and readers from the 60s into the 80s, developed the blueprint for Survive, a self-study series in several other languages (1980-83), and produced in the 1990s materials for computer-assisted language learning (CALL).

Other significant contributions to ELT have been his Longman English Grammar (1988; practice book 1990) and the Longman Advanced Grammar (1993). In these books, he made a point of looking at grammar more from the student's than the teacher's point of view. The $L E G$ has aptly been described as 'the culmination of more than thirty years' work in English as a foreign language', and in my own view deserves to be perpetuated by further writers, much as has happened with the 'classic' works of H. G. Fowler and Daniel Jones.

Though always concerned with English, Louis was far from Anglocentric in matters of language, as an example from ET7 (Jul 86) shows. In that issue, we published an interview with L. G. Alexander by Barry Tomalin of BBC English by Radio's weekly magazine Speaking of English. Part of that interview runs:

TOMALIN With courses like Look, Listen and Learn! for children, New Concept English for adults, and Follow Me on television, you were the most successful EFL textbook writer in the world. But after 1979 you seemed to move away from English as a Foreign Language and into other languages. Why?

ALEXANDER I felt that modern languages were always the poor relation of EFL. If you looked at any modern language courses, they were always a generation or two behind what we were doing in EFL. In the period of New Concept English it wasn't possible to transfer a system that was based wholly on structural grading and in particular, the structural grading of English, to the structural grading of French, for example. But once we began to work on communicative syllabuses, it struck me that these syllabuses could be used for the development of courses in other languages, and there was no reason why we shouldn't look at ways in which we could teach language through a kind of universal syllabus.

TOMALIN What kind of problems did you find when you were trying to adapt such a syllabus to French, German or Spanish? ALEXANDER The syllabus would be true for all 


\section{Alexander on language teaching: some highlights}

\section{On badly expressed and inaccurate language rules}

From the introduction to the Longman English Grammar, 1988, p. vii

Grammatical descriptions of English which are addressed to learners are often simplified and inaccurate. This is the inevitable result of lack of time in the classroom and lack of space in course books and practice books. Badly expressed and inaccurate rules, in turn, become enshrined in grammar books directed at teachers and students. The misrepresentation of English grammar gives a false view of the language, perpetuates inaccurate 'rules', and results in errors in communication.

\section{On points of grammar}

From the introduction to the Longman Advanced Grammar, 1993, p. 9

Familiar grammar points pose unusual problems because, all their learning lives, students have been given an over-simplified view of them. Common rules, such as the use of the present progressive to describe actions and events in progress at the moment of speaking, must be extended to account for sentences like People are becoming less tolerant of smoking these days. Advanced level material therefore requires a deeper understanding of grammatical structures and what they convey, as well as the elimination of persistent errors.

\section{Misconceptions about the term 'advanced'}

From the introduction to the Longman Advanced Grammar, 1993, p. 8

There are two common misconceptions about the meaning of 'advanced' .... The first is that students encounter ever more difficult structures which they have never met before, and the second is that there is a lot of 'difficult vocabulary'. The first assumption is simply not true. Structures do not exist in an ever-mounting spiral of increasing difficulty: the old, by now familiar, structures continue to be present at advanced levels. And while it is true that there is or may be a lot of 'difficult vocabulary' at advanced levels, that in itself does not constitute a difficulty which a competent dictionary cannot resolve. It is true that the way words are drawn to each other (collocation) is generally recognized to be a major feature of language acquisition and therefore a source of difficulty. Students may not always be able to produce correct and sometimes idiomatic collocations, but they have less difficulty understanding them. The capacity for reception always exceeds the capacity for production.

\section{On examinations and real life}

An item from the Ask Alexander Q/A column

I always get a high score in English exams, but my English communication is poor. Can you give me some advice?

This is a common phenomenon. Passing English exams is not the same thing as being proficient in English. Why should this be? Because passing exams means mastering exam techniques (accurately interpreting and answering the questions, finishing on time, etc.) and getting plenty of practice in all the tasks normally set in exams (multiple choice questions, usage questions, etc.). You can be good at all these 'accomplishments' and still have a rotten command of English when you need to use it in real life. The objectives of an examination and the techniques for achieving them rarely coincide with communicative skills. When do we need multiple choice in real life? Never! This problem will only be resolved when the skills required by examination boards coincide more or less precisely with the skills required for communication. Progress in this direction is extremely slow. 


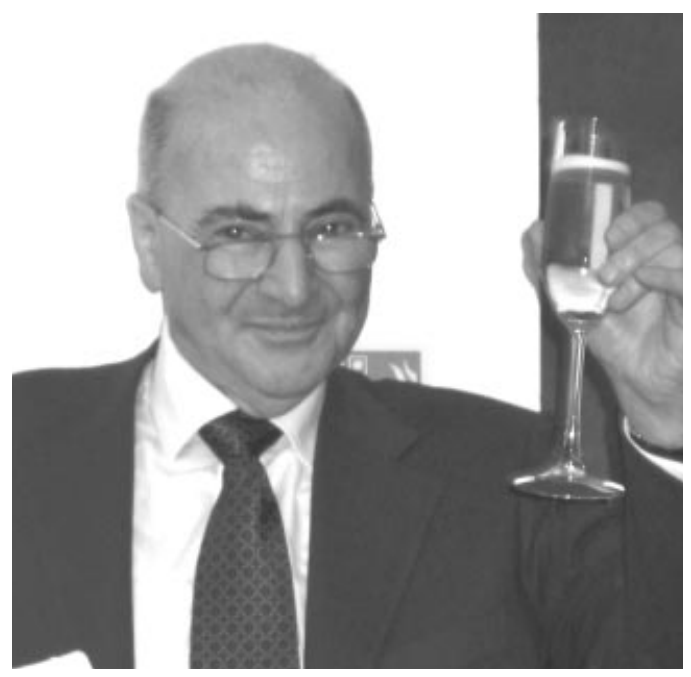

Louis Alexander in 2002

these languages in its broad outlines. What would differ was the way in which elements in the syllabus are achieved. There are universals in a communicative syllabus where you are teaching functions which are resolved in different ways by different languages. A good example is our complex tag system in English to say 'Isn't that so?', which is achieved by a simple formula in many other languages. For example, in French and German you have 'N'est-ce pas?' and 'Nicht Wahr?', which can communicate a whole multitude of things which in English we can't resolve at all easily. We need 'Wouldn't you?' and 'Hadn't he?', and so on.

TOMALIN But now you're coming back into English language teaching?

ALEXANDER I have never actually left. For the past few years I have been doing a great deal of specialized work for the Arab World.

As far as Louis was concerned, English is vital internationally, but there was, is, and always will be more to the world than any one language, however prominent. Yet, this said, one tends to return to his impact on the teaching and learning of English over some three decades.

Which is understandable. The Guinness Book of Records has noted that some 4.7 million copies of his books were sold in 1977: the greatest number of copies ever sold by one author in one year. As David Mortimer noted in his obituary in The Guardian (9 Jul 02): 'In Britain, the name of L G Alexander was not widely known, but abroad he was a celebrity: delegations met him at airports, television cameras appeared and lecture halls would be crammed with people gathered to hear him speak.' And he added: 'None of this affected his unassuming modesty or diminished the warmth and generosity of his heart.'

It is this spirit of good will, indeed goodness, that will remain with me. He helped people. For example, after returning to the UK from working in India, and while studying applied linguistics at the University of Edinburgh, I was interviewed in London as a possible researcher for a new kind of ELT wordbook. The members of the interviewing panel were distinguished and daunting, but Tim Rix of Longman took me on for the initial 'Longlex' project out of which emerged in due course the Longman Lexicon of Contemporary English (1981). For many reasons, the project was not easy, but Louis as a commentator was unfailingly supportive, and helped make a hard task easier.

He was always open to novel ideas, methods, and delivery systems, including in more recent years computer-based language courses (such as French and Spanish for Atari), interactive CD-Rom, and the Internet. We shall not easily meet his like again.

Louis George Alexander was born on 15 January 1932 and died on 17 June 2002. His first wife, Athina, died in 1979. He is survived by his daughter Marianna and son George, and his second wife Julia.

Editor's note While I was writing my obituary for Louis I was directly in touch with JULIA ALEXANDER, and in the course of our telephone and email exchanges she agreed to turn her wide-ranging comments on what I was writing into a fuller statement which I believe more than complements my own text and serves as parallel testimony to her husband's phenomenal achievements. That text follows here.

ON HOW widespread Louis' work has been in China, and for how long, perhaps I should mention that there is even a Uighur edition of New Concept English, published in Urumchi [in Xinjiang] in the early nineties, and that the authorised edition of New Concept English, published by World in Shanghai, in the period before China became a signatory to the International Copyright Convention, was said to have sold around 5 million copies a year for something like 20 years. The new (1997) edition, prepared 
in collaboration with Professor He Qixin was a radical revision, with Chinese notes, and is indeed very successful. As for Junior English For China: it was for, rather than with UNESCO. The publishers were The People's Educational Press, Beijing. Louis provided the blueprint: that is, skills syllabus and language syllabus, and Neville Grant did the writing, with Louis monitoring and advising. The standard page-size then in China was tiny, useless for classroom practice. Doubling the page size, at Louis' request, was a really radical departure, as was the book design, which was by the eminent book-designer, Paul Price-Smith. It had a huge impact, and was used by 40 million learners in China per annum for many years.

As regards Follow Me, I am assured on the best authority that it was viewed by 500 million learners, thus playing a big part in the explosion of ELT activity worldwide. I reckon if it did have 500 million learners, that would mean Lou had around 6 billion proxy students in his 40 years in print. Anyway, the whole thing with Follow Me was that it put into practice what might otherwise have remained just a set of academic papers: the Council of Europe Threshold Level syllabus. I believe that it was responsible for Threshold, which is particularly suitable for adult learners, being taken up so vigorously for the teaching of a number of embattled or minority languages, among them Welsh, Basque, and Catalan. Louis' involvement with the teaching of other languages (something that preoccupied him most between 1977 and 1981) was an inevitable outcome of his fascination with syllabus. First Things First had been adapted twenty-five years ago for teaching Dutch in Surinam and Basque (as Hitz Egin).

It was syllabus again that provoked him to write Survive in English (1979-80), the first functional/notional phrase book, in eight languages. The proposition was that the learner acquires a number of formula statements and questions ('slots'), and carries the 'fillers' - the lexicon - in his/her pocket, an approach now followed by all modern phrase books, abandoning the situational grouping of phrases (At the Shop, etc.); so Louis also revolutionised the phrasebook industry, though his work is entirely unacknowledged. (The inclusion of a VATable cassette meant that bookshops found it hard to handle - books being zero rated - so it was more imitated than sold.)

The Atari project was 4 languages: French, Spanish, Italian and German. The software publisher was actually EMI, and as happened to Louis's work pretty often, it was less wellknown than it was influential, because it was tied to the Atari machines which were rapidly overtaken by more powerful computers. It went way beyond the usual cloze tests and multiple-choice techniques used in most CAL projects, being really interactive because the Atari could activate real recorded speech, thus talking to the learner, and the Atari had a fantastic graphics capacity because of the Motorola chip.

As regards the Longman English Grammar, the original manuscript was 1,000 pages: there were seven manuscript editions and it took him seven years to write. The final version was 384 pages because that was the extent set by the publishers. But version 5, which was the final version before drastic editing down to the required extent, was the full grammar as I believed it should have been published. Louis gave the manuscript of that to Liverpool University, along with all but a treasured core of his professional books in March 1998. He chose Liverpool because they seemed to be doing good work and to be desperately short of resources.

One more note, if I may: perhaps Louis' most significant innovation is the least visible. He created the notion of the textbook as a classroom artefact or learning tool, something we take for granted today. When Louis began teaching, there was no correlation of a lesson in the book with a lesson in class. Page layouts followed similar principles to those used for publishing novels. Indexes used terms the students were unlikely to know or ever to need to know, rather than being integral to the book itself. All these principles were discussed in the extended article you commissioned from Louis for ET21 (6:1, Jan 90), which has since become a standard introduction to many teachers' courses in universities and colleges in the UK and elsewhere. 